\title{
Meningkatkan Kognitif Anak Usia Dini melalui Pengembangan Media Cube Learning
}

\author{
Koderi $^{\circledR}{ }^{\bowtie}$, Cahniyo Wijaya Kuswanto ${ }^{2}$, Sarah Nuryati ${ }^{2}$ \\ Pendidikan Bahasa Arab, Universitas Islam Negeri Raden Intan Lampung, Indonesia ${ }^{1}$ \\ Pendidikan Islam Anak Usia Dini, Universitas Islam Negeri Raden Intan Lampung, \\ Indonesia ${ }^{2}$
}

DOI: $\underline{10.31004 / o b s e s i . v 6 i 3.1824}$

\begin{abstract}
Penelitian ini bertujuan untuk meningkatkan kognitif anak usia dini melalui pengembangan Media Cube Learning. Penelitian pengembangan ini mengikuti langkah-langkah model Dick and Carey. Instrumen yang digunakan dalam mengoleksi data penelitian dengan lembar interview, lembar observasi, lembar dokumentasi lembar angket. Tanggapan ekspert materi, ekspert media, ekspert bahasa, seluruh tanggapannya berkategori "produk sangat memiliki kelayakan". Tanggapan anak-anak dari evaluasi uji one to one, small group, dan field trial, seluruh tanggapannya berkategori "produk sangat baik". Simpulan hasil pengukuran efektivitas produk menunjukan jika daya berpikir peserta didik anak usia dini dalam tingkat perkembangan kognitif, belajar dan bermain dapat ditingkatkan menggunakan media Cube Learning. Cube Learning memiliki kebaharuan dan keunggulan karena didesain menarik, penuh berbagai macam warna, gambar, angka, huruf, dan satu cube mampun memuat dua puluh delapan isi sehingga memudahkan guru memberikan pembelajaran, dan mampu membangkitkan kemauan anak-anak untuk bermain dan belajar secara psikogis, yang akhirnya meningkatkan kognitif anak usia dini.
\end{abstract}

Keywords: Cube Learning, Media, Anak Usia Dini, Kognitif.

\begin{abstract}
Abstrak
This study aims to improve early childhood cognitive through the development of Media Cube Learning. This development research follows the steps of the Dick and Carey model. The instruments used in collecting research data are interview sheets, observation sheets, questionnaire sheets documentation. Material expert responses, media experts, language experts, the responses were categorized as "highly qualified products". The children's responses from the evaluation of one to one tests, small groups, and field tests, all of the responses were categorized as "very good product". The conclusion of the measurement of product effectiveness is shows that the thinking power of early childhood students in the level of cognitive development, learning and playing can be improved using Cube Learning media. Cube Learning has novelty and advantages because it is attractively designed, full of various colors, images, numbers, letters, and one cube capable of containing twenty-eight contents making it easier for teachers to provide learning, and able to generate willingness children to play and learn psychologically, which ultimately improves early childhood cognitive.
\end{abstract}

Kata Kunci: cube learning; media, early childhood; cognitive.

Copyright (c) 2021 Koderi, et al.

$\triangle$ Corresponding author :

Email Address: koderi@radenintan.ac.id (Lampung, Indonesia)

Received 27 July 2021, Accepted 26 October 2021, Published 5 November 2021 


\section{PENDAHULUAN}

Anak usia dini sebagai anak yang mempunyai umur dari lahir (0 tahun) sampai dengan enam tahun, masa ini merupakan masa yang harus mendapatkan pendidikan, berupa rangsangan dari lingkungannya, sehingga anak memiliki perkembangan jasmani dan rohani yang baik. anak-anak usia dini tersebut, selanjutnya akan memiliki kesiapan yang baik, matang, mandiri untuk masuk pada jenjang pendidikan lanjut dari pendidikan formal berikutnya (Kutsiyyah, 2018; Wijaya Kuswanto \& Dinda Pratiwi, 2020). Peserta didik usia dini disebut the golden age, karena pada masa ini sesungguhnya mereka banyak memiliki potensi (fitrah) bagaikan kertas putih yang mudah untuk diberikan goresan kognitif apapun bentuknya (Sujiono, 2013; Syafi'i et al., 2020). Kognitif merupakan fitrah yang sudah dimiliki setiap anak-anak sejak lahir sebagai alat berpikir. Kognitif berfungsi mengolah akal agar menjadi cerdas, dalam mengamati, mengolah apa yang dilihat, dan didengar untuk menjadi konsep baru, keterampilan baru sebagai akibat dari interaksi dengan lingkungan di sekitanya. Kognitif pada dasarnya adalah kemampuan seseorang berpikir melalui daya ingat untuk menyelesaikan persoalan-persoalan dari yang sederhana sampai kepada yang sangat komplek (Pransiska, 2018). Berdasarkan kurikulum PAUD di Indonesia tahun 2009 dijelaskan bahwa perkembangan kognitif anak usia dini ditinjau dari fungsinya, anak-anak diusahakan harus mampu berkreativitas melalui alat-alat baik yang diciptakan oleh guru-guru maupun yang ada disekitar untuk dijadikan alat bermain simbolik, anak-anak harus mampu berpikir simbolik dari benda-benda yang digunakan mereka untuk bermain, apa sebabnya bendabenda bisa begini dan mengapa bisa menjadi begitu, anak-anak harus mengenal makna sederhana dari apa-apa yang mereka lihat, mereka raba, mereka dengar dalam kehidupan belajar dan bermain sehari-hari, anak-anak juga mampu mencoba berkreasi, membuat, meniru sesuai dengan kemauannya, dan pikirannya sendiri (Nurrahmawati, 2018; Wiyani, 2014).

Pola berpikir yang dimiliki anak-anak dalam belajar, bermain, dan bekerja pada hakekat itulah perkembangan kognitif. Untuk itu anak harus diberikan rangsangan melihat, meraba, dan permasalahan-permasalahn sederhana, agar anak-anak mampu memecahkan masalah secara simbolik (Nursyamsiah et al., 2019). Anak-anak usia dini belum memiliki kemampuan berpikir abstrak, oleh karena itu guru pendidikan anak usia dini harus inovasi memberikan rangsangan melalui benda-benda yang kongkrit yang dapat dilihat, diraba, dibuka, diputar tersebut sehingga anak dapat mempresentasikan secara proposional dari benda simbolik sebagai alat bermain dan belajar. Piaget dan Dianne menyatakan bahwa fitrah kognitif kongkrit adalah masa dimana anak-anak hanya mampu memahami symbol, mengklasifikasi benda, mengerti angka, paham sebab akibat dari apa yang digunakan untuk bermain, tahu arti dan identitas, serta empati dari benda-benda yang ada disekitarnya (Papalia, 2010).

Untuk itu sumber daya yang ada dilingkungan guru dan anak harus dapat didesain sedemikian rupa menjadi media pembelajaran yang cantik dan menarik sehingga dapat mempengaruhi perkembangan kognitif atau pola berpikir simbolik kongkrit anak. Menurut Blacks dan Horalsen media adalah semua benda-benda yang dapat digunakan untuk mempengaruhi komunikan, karena mampu menyampaikan pesan kongkrit, dari pembuat pesan kepada orang yang menerimanya, sehingga tujuan tercapai (Miftah, 2013, Yetri, Koderi, Amirudin, S Latifah, 2019). Untuk itu media pembelajaran sangat diperlukan dalam membantu proses perkembangan kognitif anak usia dini meliputi pengenalan suara, ukuran, bentuk, warna dan lain-lain (Karim, 2014). Media cube learning yaitu media pembelajaran sebagai alat bermain dan belajar berbentuk dadu (kubus) berlapis kain dengan memiliki warna-warna yang beragam, dapat ditempelkan bermacam-macam gambar, angka, huruf dan simbol-simbol lainnya, guna memudahkan anak-anak dalam mengklasifikasikan dan memberi arti dan makna. Media ini dikembagkan untuk mencapai perkembangan kognitif anak usia dini ditinjau dari fungsinya, anak-anak harus mampu berkreativitas memanfaat alat-alat yang telah dirancang untuk bermain simbolik, anak-anak harus mampu berpikir simbolik dari benda-benda yang digunakan mereka untuk bermain, apa sebabnya benda- 
benda bisa begini dan mengapa bisa menjadi begitu, anak-anak harus mengenal makna sederhana dari apa-apa yang mereka lihat, mereka raba, mereka dengar dalam kehidupan belajar dan bermain sehari-hari, anak-anak juga mampu mencoba berkreasi, membuat, meniru sesuai dengan kemauannya, dan pikirannya sendiri

Pengembangan media cube learning berangkat dari keyakinan bahwa media yang didesain menarik, penuh berbagai macam warna, gambar, angka, dan huruf, akan membangkitkan kemauan anak-anak untuk bermain dan belajar secara psikologis (Koderi, 2018). Pengembangan media dan penggunaannya dalam pembelajaran bermain dan belajar dengan tepat, yaitu dengan teknik, metode dan pendekatan yang sesuai karakter peserta didik the golden age, maka tujuan meningkatkan perkembangan pemikiran atau kognitif anak the golden age akan tercapai dengan baik. Menurut Arsyad bahwa media dapat meningkatkan keinginan, keyakinan, kreatifitas, minat, karena media pembelajaran yang baik, inovatif disusun agar anak-anak mudah memahami, memaknai, mengenal, mengklasifikasi, menyajikan materi dengan menarik dan terpercaya, memudahkan penafsiran materi, dan memadatkan informasi (Arsyad, 2011).

Sebelumnya telah ada penelitian yang hampir memiliki kesamaan dengan penelitian tentang peningkatan pengembangan pemikiran atau kognitif anak usia 5-6 tahun melalui pembuatan alat belajar dan bermain berupa media Cube Learning ini, perbedaannya penelitian terdahulu tersebut hanya melatih daya ingat anak saja, sedangkan Media Cube Learning ini lebih luas dalam melihat perkembangan kognitif anak meliputi anak-anak harus mampu berkreativitas memanfaatkan alat-alat-alat yang telah didesain oleh guru atau memanfaatkan semua benda disekitar tempat bermain dan belajar sebagai alat-alat bermain simbolik, anakanak harus mampu berpikir simbolik dari benda-benda yang digunakan mereka untuk bermain, apa sebabnya benda-benda bisa begini dan mengapa bisa menjadi begitu, anak-anak harus mengenal makna sederhana dari apa-apa yang mereka lihat, mereka raba, mereka dengar dalam kehidupan belajar dan bermain sehari-hari, anak-anak juga mampu mencoba berkreasi, membuat, meniru sesuai dengan kemauannya, dan pikirannya sendiri (Setiawan et al., 2012). Penelitian selanjutnya oleh Tatminingsih, yang mengatakan bahwa Alat permainan yang dikembangkan dengan konsep kemampuan kognitif, seperti: warna, bentuk, angka, huruf, urutan dan klasifikasi, serta diaplikasikan dengan terstruktur maka akan meningkatkan kognitif anak (Tatminingsih, 2019).

Penilitian terdahulu yang memiliki relevansi dengan penelitian pengembangan media cube learning ini yaitu penelitian yang dilakukan Fitriasari \& Samawi, (2020), media yang dikembangkan dengan nama media permainan Cube Up untuk merangsang emosional social anak usia 5-6. Penelitian yang dilakukan Tias, (2021), dengan produk pengembangannya media Cube letter untuk sekolah dasar, materinya tentang kata kunci-kata kunci, istilah-istilah, yang berkaitan bahasa Indonesia dan matematika sebagai pembelajaran tematik. Media cube letter memiliki keterbatasan yaitu satu cube letter terdiri hanya empat materi, sehingga guru harus membuat dalam jumlah yang banyak kubus tersebut. Persamaannya penelitian terdahulu ini berbentuk kubus dadu yang diberi warna warni hanya saja menampilkan sesuai sisi kubus yang berjumlah empat sisi, sehingga materi juga terbatas, dan apabila banyak materi guru juga mengembangkan kubus jumlahnya juga harus banyak, sehingga kurang efektif. Pengembangan model dalam penelitian ini sebagai inovasi yang diberi nama media cube learning. Media cube learning ini berupa kubus yang di desain dengan kain wall berbentuk segi empat, namun tersusun seperti slide-slide berjumlah lebih banyak sebagai tempat menempelkan materi sesuai topik permainan, tetapi ketika slide itu dilipat-lipat menjadi bentuk kubus, bisa dibolak-balik dan dibuka. Media cube learning dibuat cukup satu unit tetapi yang banyak adalah materi yang akan ditempelkan sesuai tema. Media cube learning satu unit dapat berisi 28 materi tetapi berkesan tidak jumbo, ini yang menjadi perbedaan atau novelty cube learning dari media-media yang dikembangkan sebelumnya. 
Berdasarkan data hasil analisis awal dari pra riset disimpulkan bahwa anak-anak banyak yang kurang dalam berkreasi, membuat, meniru, memaknai, pemahan mengklasifikasi warna, gambar, bentuk, angka dan huruf, menyebutkan sebagai bentuk perkembangan kognitif yang baik bagi anak-anak usia dini. Fenomena ini dalam bermain dan belajar anak karena masih didominasi oleh guru tanpa keinginan anak, belum menunjukkan anak berani menunjukkan kreatifitas mandiri. Hal ini akan menyebabkan anak menjadi pasif dalam kegiatan pembelajaran kurang mendapat kesempatan untuk mengembangkan kemampuan berpikirnya. Problem yang mendasar adalah karena belum banyak media pembelajaran sebagai alat bermain untuk meningkatkan perkembangan kognitif anak yang murah, mudah dan menarik. Media pembelajaran kognitif yang ada adalah alat media belajar yang tidak sesuai karakteristik anak-anak, dan tidak sesuai dengan tujuan bermain belajar anak yang telah dirumuskan, kurang bervariasi, pembelajaranpun monoton tidak ada kesempatan anak mengembangkan diri. Sebelumnya tidak ada penelitian tentang pengembanagn media cube learning untuk meningkatkan kognitif anak usia dini sehingga peneliti berupaya melakukan pembuatan media belajar dan bermain mampu meningkatkan kognitif anak usia the golden age, sesuai tingkat kemauan, karakter, dalam bermain dan belajar

Selanjutnya, penulis berkeyakinan bahwa untuk meningkatkan daya kembang berpikir anak tentang kognitifnya anak usia the golden age dapat dilakukan dengan dibuatkannya alat belajar dan bermain berupa media Cube Learning. Bermain dan belajar anak melalui penggunaan alat media Cube Learning akan lebih merangsang daya kemauan motoriknya, daya tarik kognitifnya, terlebih anak-anak the golden age mampu berpikir simbolik. Pengembangan alat bermain dan belajar berupa media Cube Learning diyakini mampu meningkatkan kemampuan berpikir anak the golden age, mampu mengekspresikan ide-idenyanya, tertarik untuk senang belajar dan bermain serta hati senang riang dalam mengikuti program pembelajaran di kelas maupun di luar kelas. Oleh karena itu penelitian ini diberikan mengambil judul "Meningkatkan perkembangan kognitif anak usia dini melalui Pengembangan Media cube learning".

\section{METODOLOGI}

Metode kajian ilmiah ini adalah riset dan development yaitu proses penyelidikan secara mendalam, sistematis, untuk membuat produk, serta dilanjutkan dengan memvalidasi dan uji keefektifan produk tersebut (Sugiyono, 2012).Tahap penyelidikan melalui empat langkah besar, yang diadopsi dari model Dick and Carey. Model ini digunakan dengan alasan, bahwa model Dick and Carey adalah model langkah pengembangan yang mampu digunakan bermacam-macam bentuk produk terutama produk-produk dalam system pembelajaran dan pelatihan. (Thamrin, 2014), (Obizoba, 2015), (Koderi, 2017). Metode pengumpulan data dengan wawancara, observasi, dokumetasi, dan lembar angket. Untuk mendapatkan data yang valid maka peneliti membuat alat pengumpul data wawancara, observasi, dokumetasi, dan lembar angket melalui proses mencari teori-teori yang relevan, menyusun kisi-kisi, membuat instrument dan mendiskusikannya kepada ahli media, ahli materi PAUD dan ahli bahasa Indonesia sebelum digunakan sebagai proses validasi, sehingga instrumen layak, baik dan benar.

Langkah pengembangannya 1) Penelitian pendahuluan meliputi; a) persiapan yaitu mengurus izin kelapangan, membuat instrumen dan memvalidasinya kepada ekspert konten, ekspert media dan ekspert bahasa. b) survey pendahuluan yaitu mencari data-data awal yang berkaitan dengan keadaan perkembangan anak, pola belajar dan bermain anak, pola pembelajaran yang direpkan oleh guru, materi pembelajaran guru, media pembelajaran yang digunakan guru, problem-problem yang di miliki anak, problem-problem guru dan orang tua. Semua di catatan dengan baik. c) analisis kebutuhan mengumpulkan, menyusun, melihat, mengiterpretasikan data awal guna mendapatkan hal-hal yang diperlukan oleh anak masa the golden age. 2) Desain dan pengembangan meliputi: a) mecari kebutuhan guru dan anak baik materi dan media, serta menyusunnya kedalam sebuah. b) melakukan eksekusi apa-apa yang 
telah direncanakan, c) mengidentiifkasi prilaku peserta didik. d) membuat tujuan pembelajarn baik khusus dan umum. e) membuat alat-alat tes dengan didasi oleh kisi-kisi. f) memilih metode dan strategi untuk belajar dan bermain. g) membuat bahan yang berkaitan tema binatang dan tanaman. h) pengembangan produk media permainan cube learning. 3) Evaluasi formatif yaitu untuk mengumpulkan data kelayakan produk. Evaluasi formatif berupa validasi produk dari ahli materi, media dan bahasa (Ed Forest, 2015). Uji coba produk media cube learning dilakukan pada uji one to one learning 3 anak, uji small group 6 anak. 4) Implementasi yaitu uji field trial terhadap 16 anak untuk mengetahui efektivitas produk yang dikembangkan. Tempat uji coba dan implementasi di PAUD As Salam 1, 2 dan 3 Bandar Lampung.

Selanjutnya, untuk mengetahui kebergunanaan alat belajar dan bermain berupa media cube learning dalam meningkatkan perkembangan kognitif anak usia dini, telah dilakukan penghitungan nilai pretes dan posttes. Dilakukan pengujian normalitas data dengan $U j i$ Lillefos (Ismail, 2018),(Kluz et al., 2018),Penghitungan uji Homogenitas data melalui Lji Barlett, Selanjutnya dilakukan penghitungan-t sampel berpasangan (paired test) dengan kriteria nilai $t_{\text {hitung }}$ dengan $t_{\text {tabel }}$ dengan $d k n-1$ pada nilai kepercayaan $a=0,05$. Jika $t_{\text {hitung }}>t_{\text {tabel }}$ maka $H_{0}$ tidak diterima dan $\mathrm{H}_{1}$ diterima. Namun apabila $t_{\text {hitung }}<\mathrm{t}_{\text {tabel }}$ maka $\mathrm{H}_{1}$ tidak diterima $\mathrm{H}_{0}$ diterima. Rumus yang digunakan sebagaimana dapat dilihat pada rumus 1.

$$
t=\frac{\dot{\mathrm{X}}_{1}-\dot{\mathrm{X}}_{2}}{\sqrt{\frac{\mathrm{S}_{1}{ }^{2}}{n_{1}}+\frac{\mathrm{S}_{2}{ }^{2}}{n_{2}}-2 r\left(\frac{\mathrm{S}_{1}}{\sqrt{n_{1}}}\right)\left(\frac{\mathrm{S}_{2}}{\sqrt{n_{2}}}\right)}}
$$

Rumus 1. Rumus Kebergunanaan Alat Belajar Dan Bermain (Sugiyono, 2015):

Selanjutnya digambarkan proses penelitian pengembangan media cube learning pada gambar 1 .

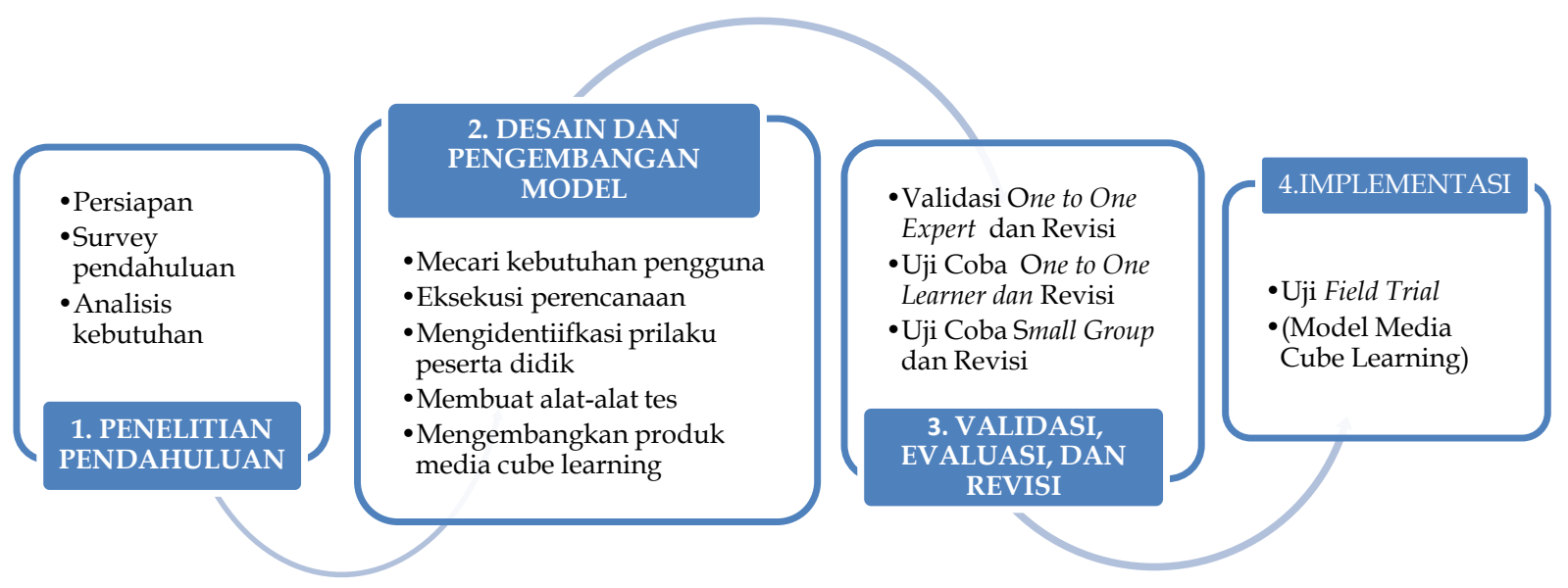

Gambar 1. Langkah-langkah pengembangan media Cube Learning

\section{HASIL DAN PEMBAHASAN}

Produk penelitian ini berbentuk media cube learning didesain mengikuti karakteristik peserta didik masa usia the golden age. Arah tujuan dari penelitian ini adalah untuk membuat media cube learning guna memfasilitasi guru dalam mengembangkan perkembangan kognitif anak usia 5-6 tahun di Indonesia. Berdasarkan hasil penelitian pendahuluan dan interview dengan guru-guru disekolah, dan melihat langsung dilapangan dijumpai peserta didik anak usia dini yang kognitifnya dalam berpikir simbolik belum memiliki perkembangan yang sesuai harapan. Fakta ini terlihat anak-anak belum bisa secara secara mengklasifikasikan kelompok binatang, kelompok tanaman, menyocokan angka dengan jumlah benda dan lain- 
lain. Hasil analisis kebutuhan menunjukkan alat dan media pembelajaran belum bervariatif keberadaannya, sehingga menjadi kendala dalam proses pembelajaran perkembangan kognitif anak usia 5-6 tahun. Strategi pembelajaran dan permainan yang menyenangkan melalui media cube learning menjadi solusi alternative.

Media pembelajaran dan permainan yang disusun, dirancang dengan inaovatif, dan dapat digunakan dengan mandiri dan berkelompok dalam belajar dan bermain, itu akan memudahkan guru dalam mengembangkan kognitif anak (Bobzien et al., 2013). Pembelajaran kooperatif menurut Slavin sebagai pola pembelajaran dimana anak-anak dapat bekerjasama dengan teman-teman belajarnya secara berkelompok sehingga mereka dapat mencapai tujuan pembelajaran secara bersama-sama (Bobzien et al., 2013). Materi pengembangan kognitif yang dikembangkan dalam media cube letter yang di modifikasi menjadi cube learning ini adalah materi dengan topic berkaitan dengan macam-macam hewan dan tumbuh-tumbuhan (Tias, 2021). Arah yang dicapai dalam belajar dan bermain menggunakan media cube learning ini yaitu peserta didik anak usia dini dapat mengklasifikasi benda-benda yang ditempel di media cube learning dengan bermain dan berpikir simbolik, anak-anak mengenal makna sederhana dari apa-apa yang mereka lihat, mereka raba, mereka dari belajar dan bermain tebak-tebak kata dengan media cube learning, anak-anak juga mampu mencoba berkreasi, membuat, meniru sesuai dengan kemauannya dari angka-angka, dan pikirannya sendiri dari media cube learning. Tujuan pembelajaran sesuai pendapat Barman (Barman et al., 2014). Gambar 2 sampai 4 adalah contoh gambar media pembelajaran cube learning dan strategi pembelajarannya.
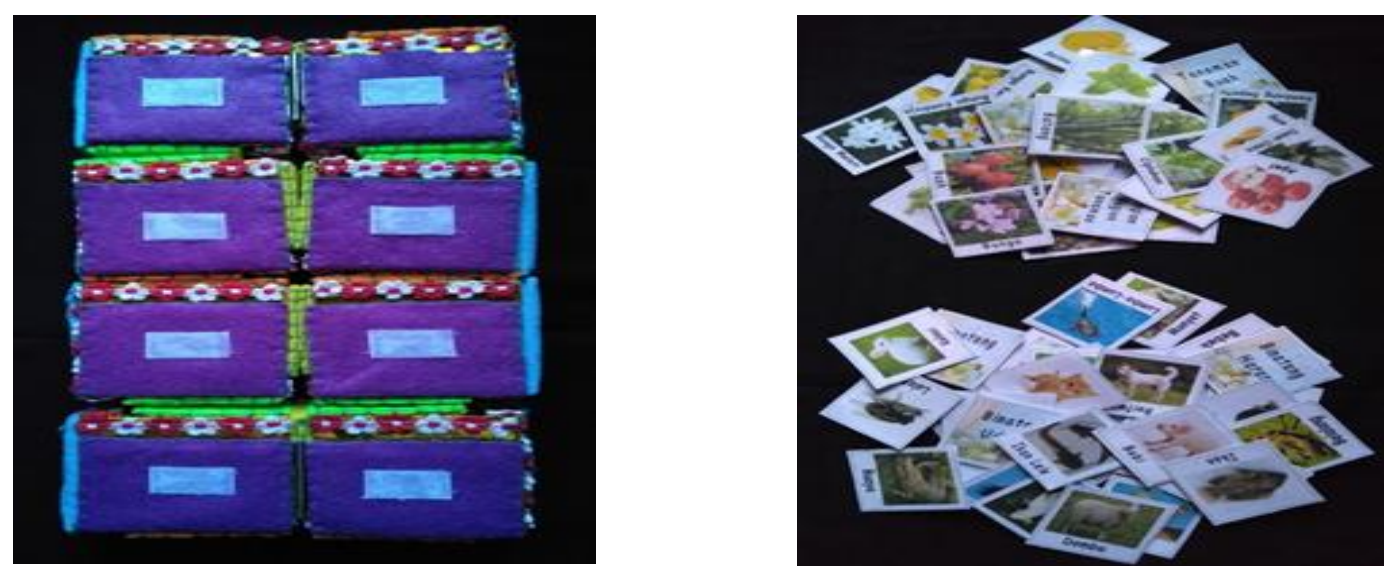

Gambar 2. Desain media cube learning
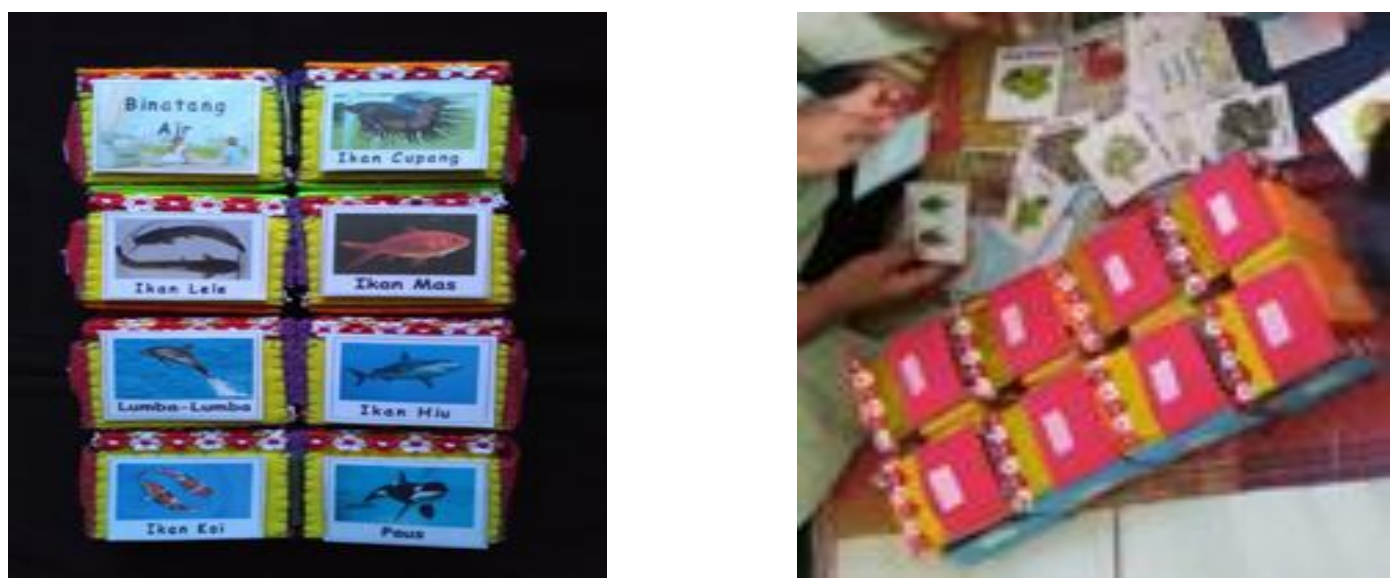

Gambar 3. Desain media cube learning 

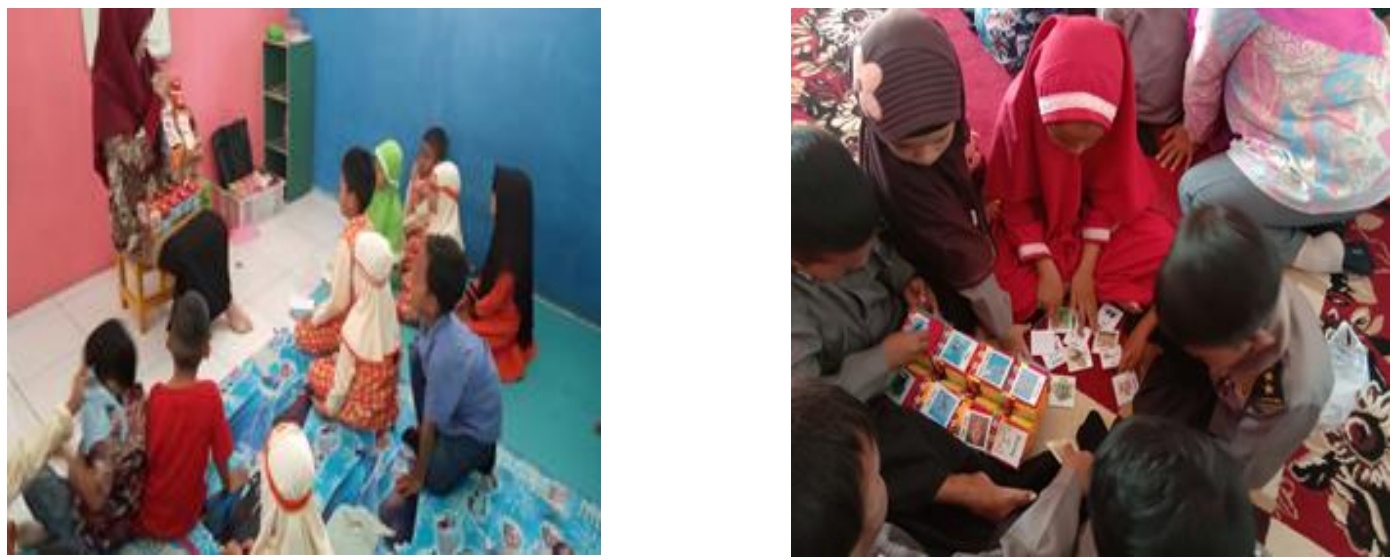

Gambar 4. Strategi pembelajaran media cube learning

Produk media cube learning yang telah dikembangkan telah dilakukan uji validasi produk terhadap ekspert konten materi, ekspert media dan ekspert bahasa. Simpulan dari penilaian ekspert materi dengan dengan nilai 3,67 atau 91,67\% "sangat layak", penilaian ahli media dengan rata-rata nilai 3,13 atau $86 \%$ "sangat layak", penilaian ahli bahasa rata-rata nilai penilaian 3,43 atau 90,63\% "sangat layak". Setelah para ahli memberikan tanggapan, bahwa produk media cube learning layak digunakan untuk pembelajaran dan permainan dalam meningkatkan kognitif anak usia dini, dan peneliti telah melakukan revisi-revisi sesuai masukannya. Pada gambar 5 digambarkan hasil tanggapan validasi ahli terhadap produk media cube learning.

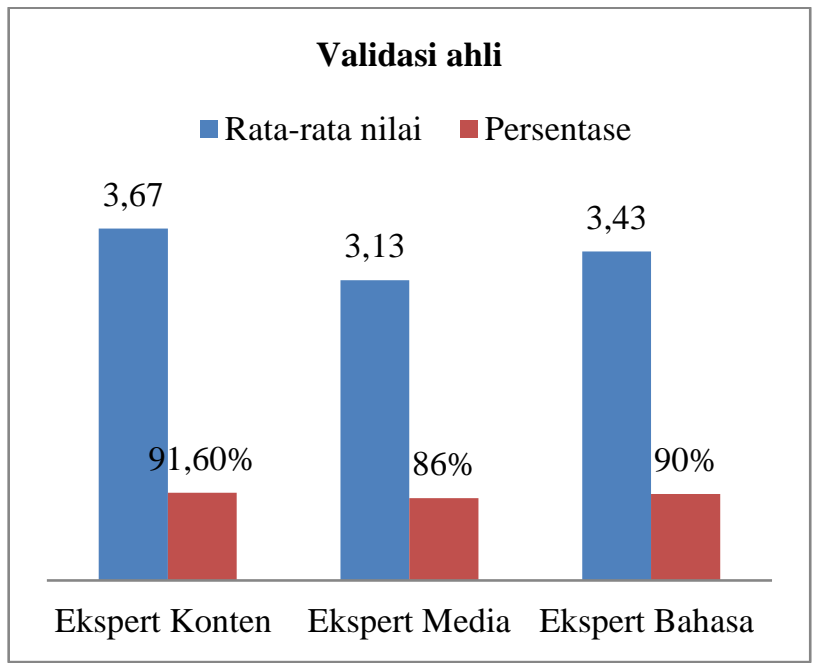

Gambar 5. Grafik Simpulan Tanggapan Ekspert

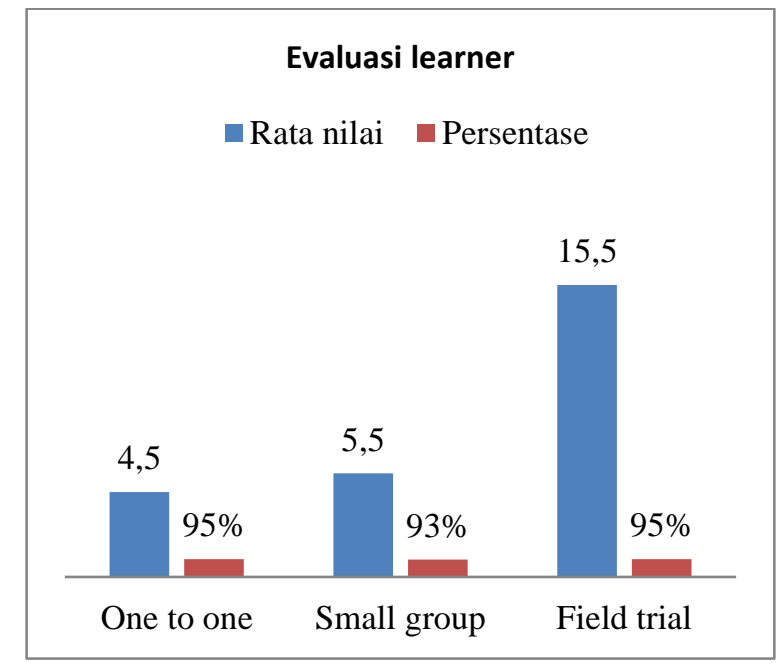

Gambar 6. Grafik hasil evaluasi learner

Selanjutnya, uji efektivitas produk melaui uji coba kepada peserta didik perseorangan, uji coba kepada peserta didik kelompok, dan uji coba kepada peserta didik jumlah yang banyak. Hasil uji coba kepada peserta didik peseorangan (one to one) dengan ratarata nilai tanggapan 4,5 atau 94\% "sangat baik", uji coba kepada peserta didik kelompok (small group) rata-rata 5,5 atau 93\% "sangat baik", uji coba kepada peserta didik jumlah banyak (field trail) rata-rata 15,5 atau 95\% "sangat baik". Hasil uji coba lapangan ini dapat dikategorikan, bahwa produk media pembalajaran cube learning yang dikembangkan dapat digunakan oleh anak-anak usia dini 5-6 tahun, walaupun mereka memiliki tingkat perkembangan yang berbeda-beda. Para pendidik dengan dibuatnya media cube learning merasa lebih senang, sangat menerima, bahkan berharap media ini dapat dibuat dalam jumlah 
yang banyak. Menurut guru-guru bahwa media ini sangat mudah digunakan dan peserta didik mudah mengikuti belajar dan bermain, yang media ini dapat menjadikan peserta didik berani mencoba dengan menempelkan benda-benda sesuai dengan berpikir simboliknya. Peserta didik dan guru bermain belajar sangat riang gembira. Gambar 6 digambarkan hasil tanggapan peserta didik terhadap produk media cube learning.

Selanjutnya, untuk mengetahui hasil efektivitas produk media pembalajaran cube learning dalam meningkatkan kognitif anak usia dini, peneliti melakukan pengukuran melalui pretes dan post tes. Hasil nilai rata-rata pre tes 14,9 ada selisih perbedaan rata-rata nilai baku 3,1. Simpulan hasil uji distribusi normal data F(zi), dan uji distribusi kumulatif S(zi) yang dihitung melalui statistic inferensial dengan nilai besaran $L_{\text {test }}=0,16595$ dengan sampel 25 dan taraf signifikan $\alpha=0,05 \mathrm{~L}_{\text {tabel }}=0,1726$. Hasil perhitungan $\mathrm{L}_{\text {test }} 0,166<\mathrm{L}_{\text {tabel }} 0,173$, oleh karena itu berkesimpulan harga hitung akhir pretes berdistribusi dalam kategoro normal. Hasil rata-rata hitung dari Post tessebesar 25,93, dengan harga selisih hitung baku 3,6. Selanjutnya hasil distribusi komulatif normalnya F(zi) dan distribusi komulatif impiris S(zi) dan mendapatkan simpulan nilai terbesar adalah $\mathrm{L}_{\text {test }}=0,132$ dengan subjek penelitian yaitu 25 orang dan tingkat kepercayaan $a=0,05 L_{\text {tabel }}=0,173$. Simpulan hitungan uji coba yaitu $L_{\text {test }} 0,132<L_{\text {tabel }} 0,173$, maka harga paling akhir dari Post tes distribusinya sangat normal.

Untuk mengetahui tingkat kesamaan data (homogenitas data) dilakukan perhitungan melalui mesin hitung aplikasi office $m s$ excel. Hasil perhitungan keanekaragaman subjek penelitian gabungan $=12,22$, nilai persatuan $B=52,18$. Hasil harga $\chi_{\text {test }}=0,0596$ dan $\chi_{\text {tabel }}$ dengan harga kepercayaan $a=0,05$ yaitu 3,85. Jadi $\chi_{\text {test }}=0,0596<\chi_{\text {tabel }}=$ 3,85 , oleh karena itu dapat ditarik pemahaman jika Hiposis nol dapat diterima artinya data uji coba berdistribusi sangat normal. Perhitungan harga pertama ketika pembelajaran dan bermain tidak memakai media cube learning hasil nilai dapat rata-rata 14,90 dan harga nilai ketika setelah belajar dan bermain memakai media cube learning 25,10 , oleh karena perbedaan antara kedua data sebelum dan sesudah menggunakan media cube learning yaitu 11,040. Berdasarkan hasil uji hitung $\mathrm{t} d \mathrm{k} n-1$ dengan harga keyakinan $\alpha=0,05$. Jadi harga $t_{\text {test }}=-18,1106$ $>t_{\text {tabel }}=2,0639$, maka hiposis nol tidak bisa diterima dan hipotesis satu dapat diterima, maknanya bahwa hasil barang sebagai produk penelitian berupa media cube learning mampu meningkankan perkembangan kognitif anak usia dini.

\section{Pembahasan}

Berdasarkan analisis awal penelitian bahwa pengembangan media cube learning ini berangkat dari problema belajar dan bermain peserta didik di sekolah PAUD. Guru-guru yang melakukan pembelajaran terutama pengembangan kognitif anak sedikit memiliki alat-alat permainan anak yang fleksibel, mudah, murah dan menarik. Anak-anak senang menggunakan karena warna-warni dan banyak variasi gambar dan huruf serta angka-angka. Guru juga ingin memiliki alat dan peraga bermain yang dapat berganti-ganti topic tapi model medianya sama, sehingga guru hanya menambah topik-topiknya saja. Guru di sekolah pendidikan anak usia dini (PAUD) dan taman kanak-kanak (TK) dituntut mampu berinovasi untuk merancang bermacam-macam alat bermain dan belajar. Merancang dan mengembangan alat bermain dan belajar atau media pembelajaran harus sesuai karakteristik anak-anak dan kebutuhan anak, serta sesuai aspek yang akan dicapai. Menurut penelitian Zaini dan Dewi bahwa media pembelajaran sebagai media belajar dan bermain mampu menstimulasi perkembangan anak usia dini, baik aspek moral agama, fisik motorik, Bahasa, social emosional dan kognitif (Dewi, 2017). Oleh karena itu media cube learning yang dikembangkan dalam penelitian ini merupakan media yang memiliki novelty, karena sebelumya belum pernah dikembangkan oleh guru dalam pembelajaran dan permaianan di pendidikan anak usia dini. Berdasarkan penilaian ahli media bahwa media cube learning yang dikembangkan sangat layak dengan rata-rata skor nilai 3,13 atau 86\%. Peneliti Tias pernah melakukan pengembangan media pembelajaran, yang diberi nama Cube letter tetapi untuk sekolah dasar, materinya tentang kata kunci-kata kunci, istilah-istilah, yang berkaitan bahasa 
Indonesia dan matematika sebagai pembelajaran tematik. Media cube letter memiliki keterbatasan yaitu satu cube letter terdiri hanya empat materi, sehingga guru harus membuat dalam jumlah yang banyak kubus tersebut (Tias, 2021).

Pengembangan media pembelajaran cube learning ini merupakan upaya cerdas yang dilakukan oleh peneliti yang berkolaborasi dengan guru dalam memfasilitasi peserta didik dalam mengikuti pembelajaran dan permainan untuk peningkatan perkembangan kognitif anak usia dini. Pengembangan media pembelajaran untuk anak usia dini, baik yang digunakan secara tatap muka di kelas luring, atau yang digunakan dalam daring, bahkan yang blended learning itu merupakan bagian dari usaha literasi guru. Hal ini sesuai dengan penelitian-penelitian terdahulu yang antara lain dilakukan Sitia Syar dan kawan-kawan (Sitia Syarh et al., 2020). Media bermain dan belajar adalah segala yang dapat digunakan untuk bermain dan belajar, sehingga peserta didik berkesan jelas, mudah dari apa-apa yang ada dalam alat tersebut, yang akhirnya peserta didik dan guru dapat mencapai tujuan (Muhtarom \& Danuri, 2019).

Media cube learning yang dikembangkan ini berupa kubus yang di desain dengan kain wall berbentuk segi empat, namun tersusun seperti slide-slide berjumlah banyak sebagai tempat menempelkan materi sesuai topik permainan, tetapi ketika slide itu dilipat-lipat menjadi bentuk kubus, bisa dibolak-balik dan dibuka. Media cube learning dibuat cukup satu unit tetapi yang banyak adalah materi yang akan ditempelkan sesuai tema. Media cube learning satu unit dapat berisi 28 materi tetapi berkesan tidak jumbo, ini yang menjadi perbedaan atau novelty cube learning dari media-media yang dikembangkan sebelumnya. Media cube learning dikembangkan untuk meningkatkan kognitif anak usia dini (Burger, 2010). Oleh karena itu berdasarkan uraian hasil pengembangan produk, dan teori-teori, maka penelitian ini dipandangan sangat bermafaat atau memiliki kegunaan bagi guru dan peserta di PAUD dan RA.

Karakteristik media cube learning yaitu materi pembelajaran dapat di rancang sesuai kebutuhan dan tema-tema yang telah ditetapkan pada silabus (Fitriasari \& Samawi, n.d.). Oleh karena itu guru harus merancang materi pembelajaran dan permaianan yang menarik untuk ditempelkan pada cube slade. Hal ini sesuai penelitian Lohmann, bahwa seorang guru harus memiliki kesadaran yang tinggi dalam memahami kebutuhan peserta didiknya, dan mampu merancang materi yang dibutuhkan tersebut sesuai kurikulum (Lohmann et al., 2018). Materi yang dirancang sesuai tujuan pembelajaran dan disampaikan dengan media yang menarik dan menyenangkan, maka akan mampu meningkatkan perkembangan kognitif peserta didik(Baharun et al., 2020).

Hasil pengukuran kognitif peserta didik dalam implementasi penelitian bahwa pada uji tes kognitif pertama dengan tidak memakai alat media cube learning mendapatkan scor komulatif 14,90 dan kumulatif harga uji tes terahir melalui penggunaan media cube learning: 25,10 , perbedaan antara penilaian tes yaitu 11,50. Berdasarkan olah simpulan dari hitung tes $\mathrm{t}$ $d k$ n-1 pada tingkat kepercayaan $a=0,05$. harga $t_{\text {test }}=-18,116>t_{\text {tabel }}=2,0639$, oleh karena itu hipotesis nol tidak dapat diterima dan hiposis satu dapat terima. Hasil penelitian ini diperkuat oleh penelitian Chamim, Nurdin dan Rinakit, bahwa rubik's cube color fuld mampu meningkatkan ketrampilan motorik dan kognitif anak usia dini, karena dengan media rubik cube anak-anak dapat bermain dimana saja, kapan saja, baik dengan teman-teman di kelas atau bersama guru (Chamim \& Adhe, 2020). Menurut Syukri dan kawan-kawan bahwa salah satu upaya untuk meningkatkan kemampuan anak dalam berhitung permulaan pada anak paud sebagai perkembangan kognitif adalah dengan menggunakan beberapa alternatif antara lain menggunakan permainan kubus bergambar (Syukri et al., 2016). Jadi berdasarkan data-data dan teori-teori yang telah dipaparkan di atas, menunjukkan jika media pembelajaran sebagai alat belajar dan bermain yang dirancang, dibuat dengan baik, menarik dan benar melalui riset sebagaimana produk penelitian media cube learning ini, akan meningkatkan perkembangan kognitif peserta didik anak usia dini. 


\section{SIMPULAN}

Produk penelitian pengembangan ini media cube learning sebagai usaha inovasi memfasilitasi guru dan peserta didik meningkatkan kognitif anak. Hasil penilaian validator ahli materi, media, bahasa bahwa produk media cube learning sangat layak". Hasil uji one to one learner, small group dan field trial dapat dikategorikan baik sekali, sehingga produk media pembalajaran cube learning yang dikembangkan dapat digunakan oleh anak-anak usia dini 56 tahun. Hasil $t_{\text {test }}$ memiliki selisih tinggi dari tabel ini bermakna bahwa penelitian pembuatan alat bermain dan belajar berupa media cube learning ini mampu menjadikan kegiatan belajar dan bermain benar-benar mampu meningkatkan perkembangan perkembangan kognitif anak usia usia dini.

\section{UCAPAN TERIMA KASIH}

Kami para peneliti mengahturkan ucapan terimakasih kepada guru, orang tua peserta didil PAUD As Salam 1,2 dan 3 Bandar Lampung yang telah membantu memberikan datadata tentang perkembangan kognitif peserta didik. Selanjutnya peneliti juga mengucapkan terimakasih kepada ekspert yang telah memvalidasi produk yang dikembangkan.

\section{DAFTAR PUSTAKA}

Arsyad, A. (2011). Media Pembelajaran. PT Raja Grafindo Persada.

Baharun, H., Zamroni, Z., Amir, A., \& Saleha, L. (2020). Pengelolaan Alat Permainan Edukatif Berbahan Limbah Dalam Meningkatkan Kecerdasan Kognitif Anak. Jurnal Obsesi : Jurnal Pendidikan Anak Usia Dini, 5(2), 1382-1395. https://doi.org/10.31004/obsesi.v5i2.763

Barman, C. R., Stein, M., Mcnair, S., \& Barman, N. S. (2014). Stdents ' Ideas About Ptants ac Plant Growth. 68(2), 73-79. https:// doi.org/10.2307/4451935

Bobzien, J., Richels, C., Raver, S. A., Hester, P., Browning, E., \& Morin, L. (2013). An Observational Study of Social Communication Skills in Eight Preschoolers with and Without Hearing Loss During Cooperative Play. Early Childhood Education Journal, 41(5), 339-346. https:// doi.org/10.1007/s10643-012-0561-6

Burger, K. (2010). How does early childhood care and education affect cognitive development? An international review of the effects of early interventions for children from different social backgrounds. Early Childhood Research Quarterly, 25(2), 140-165. https://doi.org/10.1016/j.ecresq.2009.11.001

Chamim, M. N., \& Adhe, K. R. (2020). Pengembangan Media Rubik'S Cube Color Fuld Terhadap Kemampuan Pengenalan Warna Anak Usia Dini. Pendidikan Islam Anak Usia Dini, 4(1), 1-17. https:// doi.org/10.36456/incrementapedia.vol1.no02.a2086

Dewi, K. (2017). Pentingnya Media Pembelajaran. Jurnal Pendidikan Anak Usia Dini, 1 No.1, 81-96. https:// doi.org/10.19109/ra.v1i1.1489

Ed Forest. (2015). Dick and Carey Instructional Model. In Frameworks and Theories. https://doi.org/10.4103/1995-705X.137489

Fitriasari, E. C., \& Samawi, A. (n.d.). Development Of The Cube Up Games To Stimulate Emotional Social Of 5-6 Years Children (pp. 57-64). Proceeding International Webinar Series - Educational Revolution in Post Covid Era "Teaching and Evaluation for Children in Covid Era" Faculty of Education, Universitas Negeri Malang ISBN: 978602-5445.

Ismail, F. (2018). Statistika untuk penelitian pendidikan dan ilmu-ilmu sosial. In Prenadamedia Group.

Karim, M. B. (2014). Anak Usia Dini Melalui Alat Permainan Edukatif. Jurnal PGPAUD Trunojoyo, 1(2), 103-113. 
Kluz, R., Kubit, A., \& Trzepiecinski, T. (2018). Investigations of temperature-induced errors in positioning of an industrial robot arm. Journal of Mechanical Science and Technology. https:// doi.org/10.1007/s12206-018-1040-9

Koderi. (2017). Pengembangan Modul Elektronik Berbasis SAVI Untuk Pembelajaran Bahasa Arab. Jurnal Teknologi Pendidikan, 19(3), 206-223.

Koderi. (2018). Model Development Of SAVI-Based E-Module For Arabic Instruction At Islamic Junior High School In Bandar Lampung, Indonesia. Humaniora-Binus University, 9(1), 23-31. https:/ / doi.org/10.21512/humaniora.v9i1.4136

Kutsiyyah. (2018). Peran Lembaga Paud Bagi Kesiapan Siswa Untuk Memasuki Sekolah Dasar. Kariman Jurnal Pendidikan Dan KeIslaman, 06(20), 109-128.

Lohmann, M., Hovey, K., \& Gauvreau, A. (2018). Using a Universal Design for Learning Framework to Enhance Engagement in the Early Childhood Classroom. The Journal of Special Education Apprenticeship, 7(2), 7.

Miftah, M. (2013). Fungsi dan Peran Media Pembelajaran Sebagai Upaya Peningkatan Kemampuan Belajar Siswa. Jurnal KWANGSAN, 1(2), 100. https://doi.org/10.31800/jtp.kw.v1n2.p95--105

Muhtarom, T., \& Danuri. (2019). The urgency of Interactive Animated Learning Media Development for Facilitating Literate Skills for the Student of Primary School. Journal of Physics: Conference Series, 1254(1). https://doi.org/10.1088/17426596/1254/1/012034

Nurrahmawati, E. (2018). Peranan Guru Dalam Mengembangkan Kognitif Anak Usia Dini. AlAthfaal: Jurnal Ilmiah Pendidikan Anak Usia Dini, 1(1), 83-99. https://doi.org/10.24042/ajipaud.v1i1.3380

Nursyamsiah, H., Cendana, T. P., Rohaeti, E. E., \& Alam, S. K. (2019). Kemampuan Berpikir Simbolik Anak Usia Dini Pada Usia 5 - 6 Tahun. CERIA (Cerdas Energik Responsif Inovatif Adaptif), 2(6), 286. https:// doi.org/10.22460/ceria.v2i6.p286-294

Obizoba, C. (2015). Instructional design models - Framework for innovative teaching and learning methodologies. International Journal of Higher Education Management.

Papalia, D. E. (2010). Human Development (Psikologi Perkembangan). Kencana.

Pransiska, R. (2018). Kajian Program Bilingual Terhadap Perkembangan Kognitif Anak Usia Dini Rismareni. Edukasi: Jurnal Pendidikan, 10(2), 167-178. https:// doi.org/10.31603/edukasi.v10i2.2409

Setiawan, M. T., Global, S., Mdp, I., Rajawali, J., Palembang, N., \& Selatan, S. (2012). Rancang Bangun Edugame Matching Picture 3D dengan Algoritma Depth First Search untuk Melatih Daya Ingat Anak. x, 1-13.

Sitia Syarh, E., Mayuni, I., \& Dhieni, N. (2020). Understanding Teacher's Perspectives in Media Literacy Education as an Empowerment Instrument of Blended Learning in Early Childhood Classroom. JPUD - Jurnal Pendidikan Usia Dini, 14(2), 201-214. https:// doi.org/10.21009/JPUD.142.01

Sugiyono. (2012). Metode Penelitian Pendidikan (Pendekatan Kuantitatif, Kualitatif Dan R\&D). Alfabete.

Sugiyono. (2015). Metode Penelitian Pendidikan. Bandung. In Metode Penelitian Pendidikan (Pendekatan Kuantitatif, Kualitatif, dan R\&D).

Sujiono, Y. N. (2013). Konsep Dasar Pendidikan Anak Usia Dini. Permata Puri Media.

Syafi'i, I., Sa'diyah, C., Wakhidah, E. W., \& Umah, F. M. (2020). Penerapan Video Pembelajaran Daring Anak Usia Dini Pada Masa Pandemi Covid-19. Al-Athfaal: Jurnal Ilmiah $\begin{array}{llll}\text { Pendidikan Anak Usia 140-160. } & \end{array}$ https://doi.org/10.33474/thufuli.v2i1.6925

Syukri, D., Jas, J., \& Chairilsyah, D. (2016). Picture Cubes Game Against Influence of Arithmetic the Beginning of Children Aged 5-6 Years Pengaruh Permainan Kubus Bergambar Terhadap Kemampuan Berhitung Permulaan Anak Usia 5-6 Tahun. Seling; Jurnal Program Studi PGRA, 1-15. 
DOI: 10.31004/obsesi.v6i3.1824

Tatminingsih, S. (2019). Alternatif Stimulasi Kemampuan Kognitif melalui Penerapan Model Pembelajaran Berbasis Permainan Komprehensif. Jurnal Obsesi : Jurnal Pendidikan Anak Usia Dini, 3(1), 183. https:// doi.org/10.31004/obsesi.v3i1.130

Thamrin, M. (2014). Pengembangan Bahan Ajar Penulisan Karya Ilmiah Berbasis Vokasi. Litera, 13(1), 90-102. https:// doi.org/10.21831/ltr.v13i1.1905

Tias, D. E. Y. (2021). Pengembangan Media Pembelajaran Tematik Cutter (Cube Letter) Untuk Kelas 1 Sekolah Dasar. PTK: Jurnal Tindakan Kelas, 2(1), 30-39. https://doi.org/10.53624/ptk.v2i1.54

Wijaya Kuswanto, C., \& Dinda Pratiwi, D. (2020). Pengembangan Bahan Ajar Pendidikan Jasmani untuk Anak Usia Dini Berbasis Tematik (Development of Thematic-Based Physical Education Teaching Materials for Early Childhood). Al-Athfal: Jurnal Pendidikan Anak, 6(1), 55-68. https://doi.org/10.14421/al-athfal.2020.61-05

Wiyani, N. A. (2014). Psikologi Perkembangan Anak Usia Dini. Gava Media.

Yetri, Koderi, Amirudin, S Latifah, M. D. A. (2019). The Effectiveness of Physics Demonstration Kit: The Effect on The Science Process Skills Through Students ' Critical Thinking The Effectiveness of Physics Demonstration Kit: The Effect on The Science Process Skills Through Students ' Critical Thinking. IOP Conf. Series: Journal of Physics: Conf., 1155(012061), 1-5. https://doi.org/10.1088/1742-6596/1155/1/012061 